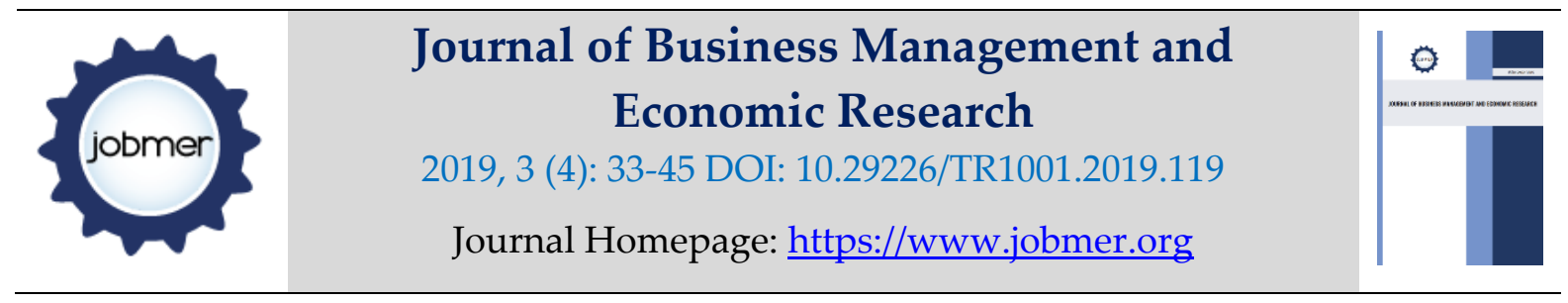

\title{
Factors Affecting Investors' Satisfaction in Industrial Zones and Results in Investment Attraction in Industrial Zones in Binh Dinh Province, Vietnam
}

\author{
Hoang Thi Hoai Huong \\ Quy Nhon University, Vietnam \\ hoangthihoaihuong@qnu.edu.vn \\ Nguyen Thi Thuy Dung \\ Quy Nhon University, Vietnam
}

\begin{abstract}
This study analyzes the factors affecting the level of satisfaction of investors and results of attracting investments in industrial zones. Research is accredited with 156/185 investors in industrial zones in Binh Dinh province (central Vietnam) with the support of SPSS software. Research findings show that the impact level of factors which attracting investment in industrial zones are arranged sequentially, from high to low as follows: investment policies and investment in developing technical infrastructure of industrial zones, human resource management, the total area of land leased and labor sizes of enterprises, and the factors affecting investors' satisfaction in the IZs as follows: invest in developing social infrastructure of industrial zones, investment in development of technical and social infrastructure of industrial zones, advantages of investment industry, management and support of local government. Finally, Research offers suggestions policy drawn from research results.
\end{abstract}

Keywords: Industrial zones, investment attraction in industrial zones, investors's satisfaction level

\section{Introduction}

Along with the comprehensive innovation in economy, the formation and development of industrial zones (IZ) in Vietnam has created a new infrastructure modernization, contributing to the rapid expansion of capital and become the important factor affecting the GDP growth rate, job creation and creating multiple additional income according to the final report on activities of model industrial zones, economic zone in 2017 of the Ministry of Planning and Investment, "Since 
established until now, foreign direct investment capital into industrial zones, annual accounts for $35 \%-40 \%$ of Vietnam's total registered additional capital; particularly, the industrial sector accounts for nearly $80 \%$. Stemming from this important role, attracting investment in industrial parks has been interested by many researchers in many aspects such as investment decisions of investors, results of investment attraction, satisfaction of investors. This study will analyze the factors affecting to two aspects are results of investment attraction and satisfaction of investors in industrial zones, thereby determining the importance of these factors to attract investment in industrial zones and and offering solutions to increase investment attraction in industrial zones.

\section{Theoretical foundations and research model}

\subsection{Theoretical foundations}

From a macro perspective, according to Dunning, three factors are ownership advantage, location advantage and advantages of internal cohesion of the enterprise to answer three questions: why multinational companies want to invest abroad, which locations are selected for investment and how does implementation of investment. In the cost approach, Badri (1996) collected data of a total of 2125 CEOs of companies in 23 countries worldwide and indicated that the main factors affecting industrial location choice of investors is transport infrastructure, labor, materials, markets, industrial clusters, government support and management, taxes, climate and social communities.

Nguyen Dinh Tho (2009) studied the factors affecting investors' satisfaction including basic business infrastructure (basic infrastructure, labor, land use right, school quality). , Local government support (trade support, investment incentives, public services) and quality of life. Nguyen Manh Toan (2010)concluded that the technical infrastructure development is the most important factor, The following are respectively incentives and investment support of the local government; low operating costs; potential market, geographic location and social infrastructure affects the decided to choose the location to invest in local of investors. Dinh Phi Ho (2012) used survey data from 226 enterprises in industrial zones in Vietnam to assess factors affecting investment attraction in industrial zones. The results show that the infrastructure factor is the most influential factor to attract investment in industrial zones besides the investment policy regime; 
living and working environment; investment industry advantages; quality of public services; local brand; human resources; competitive input costs.

\subsection{Proposed research model}

The author builds a research model based on the research of Nguyen Dinh Tho (2009) and Dinh Phi Ho (2012) as follows:

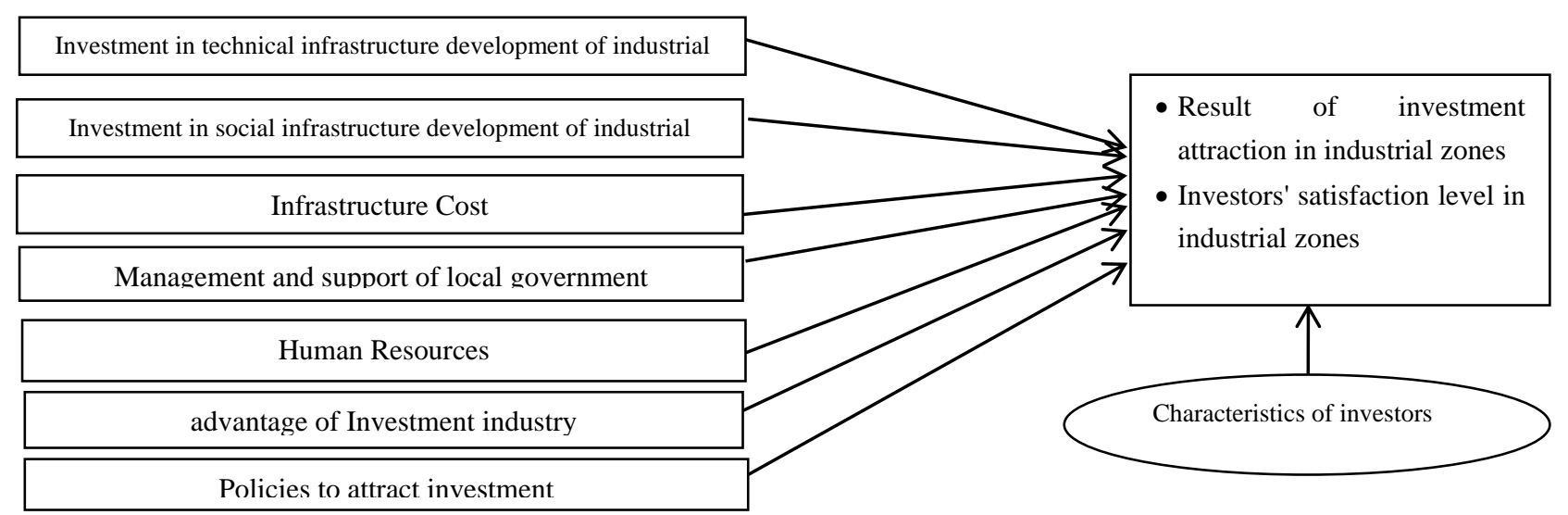

Figure 1: Model of evaluation of factors affecting the results of attracting investment in industrial zones and investors' satisfaction in IZs

Research model proposed independent variables, control variables as follows:

i. Control variable: The author uses control variables as characteristics of the investor. Stiglitz (1988) argues that investors must always make decisions to carry out a certain investment activity. Studies by Nguyen Minh Ha, Nguyen Duy Khuong (2014), Nguyen Phuc Nguyen (2013) have demonstrated the relationship between investors' characteristics and investment attraction. Referring to previous studies, the author uses the characteristics of investors as area of land leased and labor sizes

ii. Independent variables:

Investment in infrastructure development of industrial zones: Based on the content of the investment activity in infrastructure development in industrial zones and refer to some previous studies of Nguyen Dinh Tho (2009), Dinh Phi Ho (2012); Ha Nam Khanh Giao and colleagues (2015) separated the factor "investment in developing infrastructure of industrial zones" into two factors: investment 
in developing technical infrastructure of industrial zones and investment in developing social infrastructure of industrial zones.

Human Resources: Human resource is the entire professional process that people accumulate; it appreciated the income potential in future (Begg et al., 2007). The author uses the following criteria to measure human resources based on previous studies, especially of Dunning (1997), Dinh Phi Ho (2012).

Policies to attract investment: Rosenfeld (1996) found a positive impact of policies on investment cooperation in Denmark. Similarly, Kipping (1996) also discovered the role of the government in developing industries in France and Germany. The author uses the criteria to measure investment policies based on previous studies by Dunning (1997), Kotler (2002), and Ha Nam Khanh Giao and colleagues (2015).

Management and support of local government: according to Vu Minh Khuong, Haughton (2003), Malesky et al. (2009) argue that local government efforts are a very important factor to improve the investment environment and attract investment in the locality and Industrial zone. Supportation can from the government including policies for socio-economic development of the state in general; besides that also from the local specifically the Industrial Zone Management Board of the province / city. Author based on research by Barro et al (1997), Nguyen Manh Toan (2010), the survey PCI 2014 to propose criterias for measuring this factor.

Investment industry advantages: The investment industry advantage can be the working relationships between support companies and localities, input suppliers can create favorable conditions for the process of innovation and upgrading (Porter, 1998). Reference to the study of Dunning (1997), Kotler (2002) to select criterias to measure the advantage factor of the investment industry Cost for use of infrastructure: Studies of Kotler (2002), Nguyen Manh Toan (2010) agreed that a reasonable operating costs will be an important factor affecting the investment attraction.. References from previous studies of Nguyen Manh Toan (2010) to develop criteria for measuring the cost for use of infrastructure

iii. Dependent variable

Result of attracting investment in industrial zones: In this study, the author uses the scale of investment capital disbursed 
Satisfaction level of investors in industrial zones: according to Kotler (2000), Satisfaction as "a person's feelings of pleasure or disappointment resulting from comparing a product's perceived performance in relation to his or her expectations". The scale of investors' satisfaction in the IZ is based on the research of Nguyen Dinh Tho (2009) and Dinh Phi Ho (2012).

\section{Research findings}

\subsection{Research area}

The research area is located in industrial zones in Binh Dinh province, which is a province in the South Central Coast of Vietnam. By the end of December 2015, in the industrial zones in Binh Dinh province, there were 185 investors with 219 investment projects. The author with the help of the Economic Zone Management Board in Binh Dinh Province has sent the survey to all 185 investors in industrial zones. As a result, the author received 170 responses with $91.89 \%$ overall. After cleaning, remove invalid votes (blank, incomplete) and 156 votes reached 84.32\% compared with the overall.

Table 1: Descriptive statistics of sample by occupation

\begin{tabular}{|l|c|c|}
\hline \multicolumn{1}{|c|}{ Criteria } & $\begin{array}{c}\text { Number of } \\
\text { enterprise }\end{array}$ & Rate compare with overall \\
\hline Forest products processing & 45 & $25,47 \%$ \\
\hline Paper material (shavings) & 12 & $7,05 \%$ \\
\hline Granite processing & 22 & $12,94 \%$ \\
\hline Mechanical and construction materials & 11 & $6,48 \%$ \\
\hline Paper processing, packaging & 10 & $5,88 \%$ \\
\hline Animal feed & 13 & $7,65 \%$ \\
\hline Agricultural processing & 21 & $12,35 \%$ \\
\hline Supporting industries & 9 & $5,3 \%$ \\
\hline Other professions & 27 & $15,88 \%$ \\
\hline
\end{tabular}

Source: Compiled by authors from research results

\subsection{Scale and quality control scale}


Based on the theory proposed by the author, synthesize and complete the scales for the factors and variables in the model. The scales used by the author are based on SERVQUAL (Parasuraman) and based on the scale of studies of Nguyen Dinh Tho (2009) and Dinh Phi Ho (2012). The criteria of the research model are as follows:

Table 2: Criteria of research model

\begin{tabular}{|c|c|c|}
\hline \multicolumn{2}{|r|}{ SCALES } & \multirow{2}{*}{$\begin{array}{c}\text { KÍ HIỆU } \\
\text { HTKT } \\
\end{array}$} \\
\hline & Investment in developing technical infrastructure of industrial zones & \\
\hline 1 & Convenient transportation infrastructure & HTKT1 \\
\hline 2 & Stable power supply system & HTKT2 \\
\hline 3 & Stable water supply and drainage system & HTKT3 \\
\hline 4 & Green infrastructure are well invested & HTKT4 \\
\hline 5 & Convenient communication system & HTKT5 \\
\hline 6 & Waste treatment system is well invested & HTKT6 \\
\hline \multicolumn{2}{|r|}{ II. Investment in developing technical infrastructure of industrial zones } & HTXH \\
\hline 1 & Medical infrastructure investment meeting the demand & HTXH1 \\
\hline 2 & School system satisfies the demand & HTXH2 \\
\hline 3 & Entertainment service system satisfies demand & HTXH3 \\
\hline 4 & Housing infrastructure satisfies the needs & HTXH4 \\
\hline \multicolumn{2}{|r|}{ III. Human resources } & NNL \\
\hline 1 & Labor quality meets the requirements of investors & NNL1 \\
\hline 2 & Abundant labor resources & NNL2 \\
\hline 3 & The Cost of Cheap Labor & NNL3 \\
\hline 4 & Labourers have career skills, and abilities that are good apply in technology & NNL4 \\
\hline 5 & Hiring good managers the easy way in locality & NNL5 \\
\hline 6 & Highly disciplined labours & NNL6 \\
\hline \multicolumn{2}{|r|}{ IV. Investment policy } & CSDT \\
\hline 1 & Preferential policies of local investment is reasonable & CSDT1 \\
\hline 2 & Legal documents are be deployed quickly to investors & CSDT2 \\
\hline 3 & The tax system is clear & CSDT3 \\
\hline 5 & Administrative procedures simple, fast & CSDT4 \\
\hline \multicolumn{2}{|r|}{ V. Management factors and support of local government } & CQDP \\
\hline 1 & Local leaders are willing to support investors & CQĐP1 \\
\hline 2 & Local government have a good support policies for investors & CQĐP2 \\
\hline 3 & Questions and feedback of enterprises are always answered satisfactorily & CQĐP3 \\
\hline 4 & Managers have good qualifications, skills and attitude of service & CQĐP4 \\
\hline \multicolumn{2}{|r|}{ VI. Advantages of the investment sector } & LTDT \\
\hline 1 & Easy to approach with input factors & LTĐT1 \\
\hline 2 & Development of supporting industries & LTĐT2 \\
\hline 3 & Advantageous consumer markets & LTĐT3 \\
\hline 4 & Advantageous geographical location & LTĐT4 \\
\hline \multicolumn{2}{|r|}{ VII. The cost of using the infrastructure } & CPHT \\
\hline
\end{tabular}




\begin{tabular}{|l|l|c|}
\hline 1 & Prices of communications services is reasonable & CPHT1 \\
\hline 2 & Electricity prices, water prices, freight rates are reasonable & CPHT2 \\
\hline 3 & A land lease prices is reasonable & CPHT3 \\
\hline 4 & Cost of waste disposal reasonable & CPHT4 \\
\hline \multicolumn{2}{|l|}{ VIII. The satisfaction level of investors } & MHL \\
\hline 1 & The industrial zone meets expectations & MHL1 \\
\hline 2 & Satisfied with the infrastructure system invested by the IZs & MHL2 \\
\hline 3 & Continuing to invest in the local industrial park & MHL3 \\
\hline 4 & Introducing the IZ in this locality to other investors & MHL4 \\
\hline 5 & Overall, Satisfied when investing in the industrial zone & MHL5 \\
\hline
\end{tabular}

Source: Compiled from the research results of the author

\subsection{Testing scale's quality}

According to Nunally and Burnstein (1994) the scales and observed variables can be used if it satisfy: The Cronbach's Alpha coefficient of the overall scale is larger than or equal to 0.6 and the correlation coefficient of the sum of the observed variables in the scale must be larger than or equal to 0.3 . The results of the scale test of the study meet the above conditions as follows:

Table 3: Testing scale quality

\begin{tabular}{|l|c|}
\hline \multicolumn{1}{|c|}{ Group of factors } & Cronbach's Alpha Coefficient \\
\hline The satisfaction level of investors & $\alpha=0,834$ \\
\hline Investment in developing technical infrastructure & $\alpha=0,758$ \\
\hline Investment in developing social infrastructure & $\alpha=0,753$ \\
\hline Advantages of the investment sector & $\alpha=0,774$ \\
\hline Management factors and support of local government & $\alpha=0,818$ \\
\hline The cost of using the infrastructure & $\alpha=0,865$ \\
\hline Investment policy & $\alpha=0,833$ \\
\hline Human resources & $\alpha=0,838$ \\
\hline
\end{tabular}

Source: Compiled from the research results of the author

\subsection{Analysis of discovery factors}

After testing the quality of scale, the author removed the scale, the observed variable did not satisfy the condition and continued to analyze the discovery factor. According to Hair et.al (1998), EFA analysis is considered appropriate when the following conditions are satisfied: Multiplying the load factor Factor Loading > 0.55; $0.5 \leq \mathrm{KMO} \leq 1$; Bartlett's test has statistical significance Sig. $<0.05$; The variance method (Cumulative $\%$ of variance) $>50 \%$. The results of exploratory analysis are as follows: 
Table 4: Exploratory factor analysis

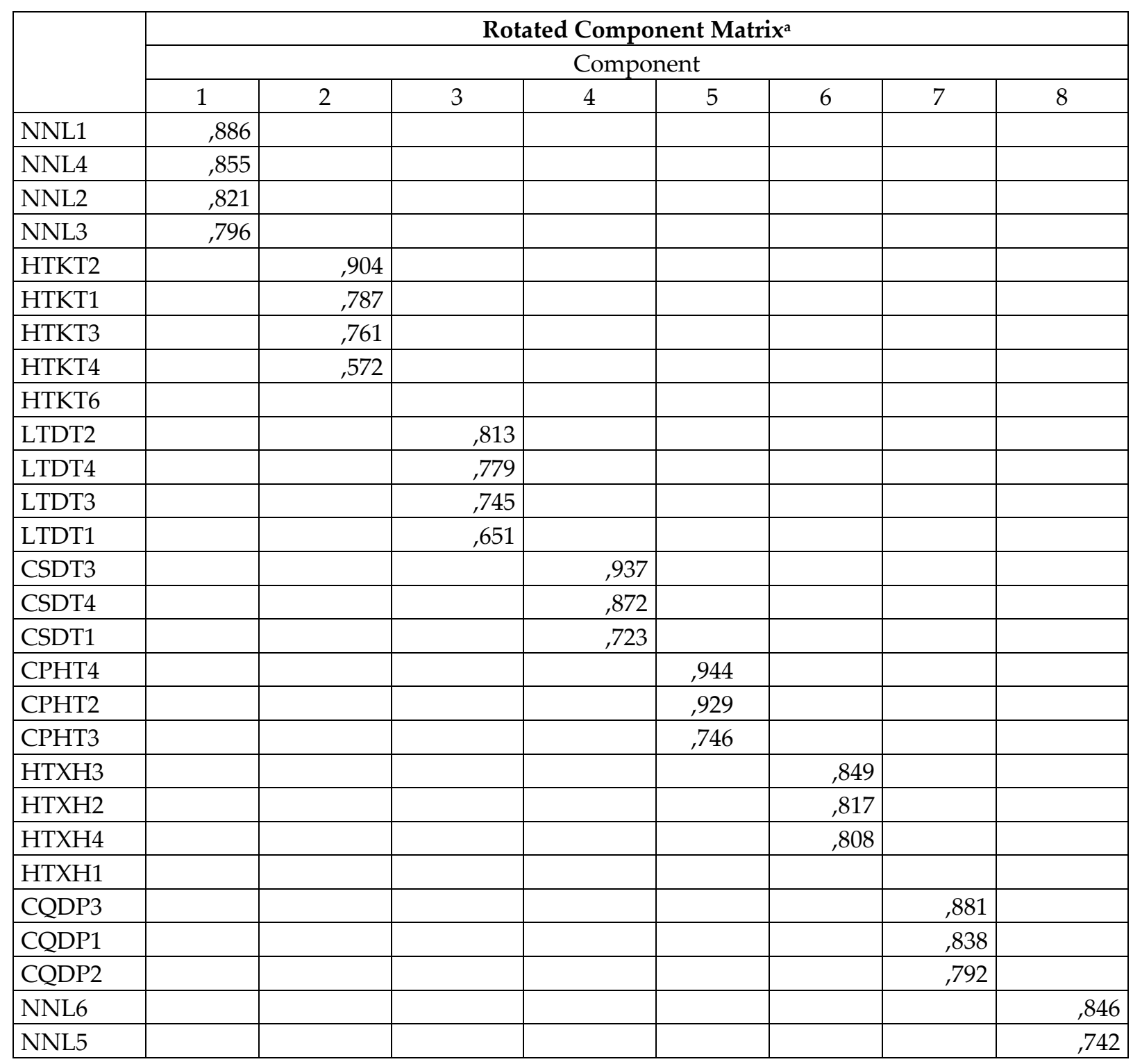

Source: Compiled from the research results of the author

Results of $\mathrm{KMO}$ analysis $=0.653$; Bartlett test has statistical significance Sig. $=0,000<0.05$ indicates that the observations are correlated in the overall with $99 \%$ significance level and the variance extracted is 73,435 indicating 73,435\% variation of observed variables explained by 8 factors drawn. It can be concluded that EFA analysis is appropriate.

\subsubsection{Regression results}


Based on the results of scale test, there are 8 independent variables as above EFA analysis and 2 control variables are land lease area, labors scale,, the dependent variable of model is realized capital and investor satisfaction the author conducts regression analysis to estimate the impact level of factors.

\subsubsection{Factors affecting the results of investment attraction in industrial zones}

The results of investment attraction in industrial zones are measured by realized capital criteria. The general regression model is estimated as follows: VTH $=\beta 0+\beta 1 \mathrm{DTT}+\beta 2 \mathrm{LD}+\beta 3 \mathrm{NNLA}+$ $\beta 4 \mathrm{NNLB}+\beta 5 \mathrm{CSDT}+\beta 6 \mathrm{LTDT}+\beta 7 \mathrm{CPHT}+\beta 8 \mathrm{CQDP}+\beta 9 \mathrm{HTXH}+\beta 10 \mathrm{HTKT}+\mathrm{ei}$

The results of regression analysis of variables in the model are presented in the table below.

Table 5: Regression results

\begin{tabular}{|c|c|c|c|c|c|c|c|}
\hline \multirow{2}{*}{\multicolumn{2}{|c|}{ Model }} & \multicolumn{2}{|c|}{$\begin{array}{l}\text { Unstandardized } \\
\text { Coefficients }\end{array}$} & \multirow{2}{*}{$\begin{array}{l}\text { Standardized } \\
\text { Coefficients } \\
\text { Beta }\end{array}$} & \multirow[t]{2}{*}{$\mathrm{t}$} & \multirow[t]{2}{*}{ Sig. } & \multirow[t]{2}{*}{ VIF } \\
\hline & & $\mathrm{B}$ & Std. Error & & & & \\
\hline \multirow{11}{*}{1} & (Constant) & $-79,042$ & 18,806 & & $-4,203$ & ,000 & \\
\hline & DTT & ,154 & ,045 & 224 & 3,456 & ,001 & 1,112 \\
\hline & LD & ,030 & ,009 & 213 & 3,405 & 001 & 1,043 \\
\hline & NNLA & 3,070 & 2,266 & ,095 & 1,355 & ,178 & 1,301 \\
\hline & NNLB & 3,852 & 2,255 & 117 & 1,708 & ,090 & 1,249 \\
\hline & CSDT & 13,461 & 1,953 & ,466 & 6,892 & ,000 & 1,218 \\
\hline & LTDT & 3,171 & 2,960 & ,070 & 1,071 & ,286 & 1,133 \\
\hline & $\mathrm{CPHT}$ & 2,392 & 1,702 & ,088 & 1,405 & ,162 & 1,055 \\
\hline & CQDP &,- 113 & 2,411 &,- 003 & -047 & 963 & 1,107 \\
\hline & HTXH & 1,101 & 2,707 & ,027 & ,407 & ,685 & 1,134 \\
\hline & HTKT & 4,445 & 2,400 & 119 & 1,852 & ,066 & 1.096 \\
\hline \multicolumn{8}{|c|}{ a. Dependent Variable: VTH } \\
\hline
\end{tabular}

Source: Compiled from the research results of the author

R2 modify the model is 0.417 meaning that the independent variables of the model explain $41.7 \%$ of the variation of the dependent variable. The coefficient VIF also tells us that there is no multicollinearity phenomenon in the model. In the analysis table Anova variance shows: the Fvalue of the model with Sig level. = 0,000, thus it can be concluded that the model fit the actual data. 


\subsubsection{Factors affecting the level of satisfaction of investors in industrial zones}

The general regression model with the dependent variable is the level of investor satisfaction estimated as follows: $\mathrm{MHL}=\beta 0+\beta 1 \mathrm{DTT}+\beta 2 \mathrm{LD}+\beta 3 \mathrm{NNLA}+\beta 4 \mathrm{NNLB}+\beta 5 \mathrm{CSDT}+\beta 6 \mathrm{LTDT}+$ $\beta 7 \mathrm{CPHT}+\mathrm{C} 8 \mathrm{CQDP}+\beta 9 \mathrm{HTXH}+\beta 10 \mathrm{HTKT}+\mathrm{ei}$

The results of regression analysis of the variables in the model are as follows:

Table 6: Regression results

\begin{tabular}{|c|c|c|c|c|c|c|c|}
\hline & \multicolumn{2}{|c|}{$\begin{array}{l}\text { Unstandardized } \\
\text { Coefficients }\end{array}$} & \multirow{2}{*}{$\begin{array}{c}\begin{array}{c}\text { Standardize } \\
\mathrm{d} \\
\text { Coefficients }\end{array} \\
\text { Beta }\end{array}$} & \multirow[t]{2}{*}{$\mathrm{t}$} & \multirow[t]{2}{*}{ Sig. } & \multirow[t]{2}{*}{ VIF } \\
\hline & & B & Std. Error & & & & \\
\hline \multirow{11}{*}{1} & (Constant) & ,930 &, 420 & & 2,213 & , 028 & \\
\hline & DTT &,- 001 & , 001 &,- 043 &,- 615 & , 540 & 1,112 \\
\hline & LD &, 000 & , 000 &,- 058 &,- 853 & ,395 & 1,043 \\
\hline & NNLA &,- 052 & ,051 &,- 079 & $-1,036$ & ,302 & 1,301 \\
\hline & NNLB & ,037 & ,050 & ,055 & ,737 & ,463 & 1,249 \\
\hline & CSDT & ,008 & ,044 & ,013 & 177 & , 860 & 1,218 \\
\hline & LTDT & ,164 & ,066 & ,177 & 2,478 & ,014 & 1,133 \\
\hline & СРНТ & , 029 & , 038 & ,053 & ,766 & , 445 & 1,055 \\
\hline & CQDP & ,111 &, 054 & ,146 & 2,066 & ,041 & 1,107 \\
\hline & НTХН & ,306 & , 060 & 361 & 5,065 & , & 1,134 \\
\hline & HTKT & 182 & ,054 & 238 & 3,398 & ,001 & 1,096 \\
\hline
\end{tabular}

Source: Compiled from the research results of the author

Research Findings also included R2 of the model of 0.305, which means that the independent variables included in the model explain $30.5 \%$ of the variation of the dependent variable. The VIF coefficient also indicates that there is no multicollinearity phenomenon in the model. In the Anova variance analysis table: F statistics of the model with Sig level. $=0,000$, it can be concluded that the given model is consistent with actual data

\section{Conclusions and policy suggestions}

\subsection{Conclusion}

Based on the relevant theoretical system, the study has developed a theoretical model consisting of 7 factors with 33 observed variables to analyze the factors affecting the results of investment attraction in the industrial zones and the satisfaction of investor industrial zones. After verifying 
the scale's quality and analyzing the exploratory factor, the original model has been adjusted with 8 factors with 26 observed variables: investment in developing technical infrastructure of industrial zones, investment in social infrastructure development in industrial zones, investment policies, infrastructure use costs and advantage of investment industry, management labor.

After performing OLS regression, we see the level of impact on attracting and investment attraction in industrial zones is arranged from high to low sequentially as follows: investment policy $(\beta=$ $13,461)$, investment in technical infrastructure development of industrial zones $(\beta=4,445)$, management labor $(\beta=3,852)$, land lease area $(\beta=0,154)$, and the labor size of the enterprise $(\beta=$ $0.030)$.

Similarly, we also have group of investment in social infrastructure development is the most factor which impacted to the satisfaction of investors in the model with $(\beta=0.306)$, investment in technical infrastructure development is the second most factor impacted with $(\beta=0.182)$, in the research model (in which the advantage group of investment sector with $(\beta=0.164)$, management and support of local goverment with $(\beta=0.111)$

\subsection{Policy suggestions}

According to analysis results, investment in technical infrastructure development in industrial zones has positive, therefore, improving the quality of investment and development of technical infrastructure of industrial zones to create a synchronous and modern infrastructure system and satisfaction of investors is very important. After the project comes into operation, the operation and management phase should also be strictly implemented so that the infrastructure system can maximize its capacity, best serving to the business investment activities of the investor.

Due to above issues, it is necessary to pay attention to all phases of investment activities from preparing investment to operating results of the investment in technical infrastructure development.

Research findings also show that investment in social infrastructure development in industrial zones is not statistically significant in the research model to the attraction results but it positively impacts investors' satisfaction. Thus, it is necessary to pay attention to the social infrastructure of industrial zones, which can enhance the coordination between the goverment and the infrastructure 
investors of industrial zones to develop this content. Investment attraction policies have the strongest impact on the results of attracting investment in industrial zones.

Therefore, the management agencies focuses on completing policies to attract investment in production and business to create the best conditions for localities as well as infrastructure investors in attracting investment in industrial zones. Currently, industrial zones in the area are implemented by domestic investors. Binh Dinh province may consider in making policies to encourage foreign investors to contribute capital or make investment in infrastructure development industrial zones. Or allow a group of domestic and foreign investors to cooperate with each other to invest in developing infrastructure of industrial zones

\section{References}

Badri, Masood A. (2007), "Dimensions of industrial location factors: Review and exploration", accessed11/08/2018 at link:

https://www.researchgate.net/publication/262562595_Dimensions_of_industrial_location_f actors_Review_and_exploration

Barro, R.J., and Sala-i-MartinX. X (1997), "Technological Diffusion, Convergence and Growth", Journal of Economic Growth 2 (March): 1- 26.

Begg, Stephen, Vos, Theo, Barker, Bridget, Stevenson, Chris, Stanley, Lucy and Lopez, Alan D. (2007), The burden of disease and injury in Australia 2003, accessed 10/03/2015 at link http://dro.deakin.edu.au/eserv/DU:30046702/stevensonburdenofdisease-2003.pdf

Dunning, J.H. and Narula, R. (1995), "The R\&D Activities of Foreign Firms in the United States", International Studies of Management \& Organisation, 25 (1-2), 39-73.

Dinh Phi Ho (2012), Quantitative research methods and practical research in agrarianeconomics, Orient Publishing House

Ha Nam Khanh Giao, Le Quang Huy, Ha Kim Hong, Huynh Diep Tram Anh (2015), "Study the factors affecting to investment attraction in Ca Mau province", Ho Chi Minh City Open University, Science Journal., No. 5 (44)

Hair \& ctg (1998,111), Multivariate Data Analysis, Prentice-Hall International, Inc.

Kipping, M.(1996), "Inter-firm relations and industrial policy: The French and German steel producers and users in the twentieth century", Business History, Vol. 38, pp. 125.

Kotler, P., M. A. Hamlin, I. Rein, and D. H. Haider. 2002. Marketing Asian places: Attracting investment, industry, and tourism to cities, states, and nations. Singapore: John Wiley (Asia).

Le Viet Anh (2004), FDI-Growth Nexus in Vietnam, accessed on 20/06/2015 at http://www.grips.ac.jp/vietnam/VDFTokyo/Doc/1stConf18Jun05/Paper(LeVieAnh).p df 
Malesky, E., Jensen, NM.and Weymouth, S. (2009), "Unbundling the relationship between authoritarian legislatures and political risk", British Journal of Political Science , 44 (3), 655-684

Nguyen Dinh Cung (2004), Scientific basis and policy solution to reduce business costs, improve Vietnam's competitiveness, Scientific research topics at Ministry level

Nguyen Dinh Tho (2009), Place Development: Attributes and Business Customer Satisfaction in Tien Giang Province, Vietnam, Journal Macromaketing 29 (4) 384 391

Nguyen Manh Toan (2010), "Factors affecting the attraction of foreign direct investment into a locality of Vietnam", Science and Technology Journal - Danang University, vol 40, page 270 - 276

Nguyen Minh Ha and Nguyen Duy Khuong (2015), "Factors affecting investment of enterprises in industrial zones and industrial clusters in Tien Giang province", Scientific Journal of Ho Chi Minh Open University in Ho Chi Minh City, No. 1 (40) 2015.

Nguyen Phuc Nguyen (2013), " Factors affecting investment in industrial parks in Central Viet Nam, Economics and Development Journal, No. 192, page 50-55

Nunnally, J. C. and Bernstein, I. H. (1994), Psychometric Theory (3rd Ed.), New York: McGraw - Hill.

Porter, M. (1998), "The Microeconomic Foundations of Economic Development", The Global Competitiveness Report, (pp. 38-63)

Rosenfeld, S. A. (1996), "Does cooperation enhance competitiveness? Assessing the impacts of inter-firm collaboration", Research Policy, Vol. 25, pp. 247 - 263.

Stiglitz, Z.E. (1998), Public economics, Science and Technology Publishing House

Vu Minh Khuong, Haughton, J. (2003), The Competitiveness of Vietnam's three largest cities, truy cập ngày 12/01/2015 tại địa chỉ: https://sites.hks.harvard.edu/mrcbg/ptep/khuongvu/The\%20Competitiveness\%20of\%20Vietnams\%20Three\%20Lar gest\%20Cities.pdf 